UDC. 621.175.1: 621.187.1

DOI: https://doi.org/10.20535/2218-93002522019188250

\title{
SALTS CONCENTRATION AND DEPOSITION IN POWER PLANT COOLING SYSTEMS
}

\author{
Kochmarskii V.Z., Kuba V.V. \\ National University of Water and Environmental Engineering, Physical and technological \\ laboratory of water systems. Rivne, v.z.kochmarskii@nuwm.edu.ua
}

\begin{tabular}{|l|} 
Article history: \\
Received: 17 October 2019 \\
Accepted: 1 November 2019 \\
Print: 20 December 2019
\end{tabular}

with the thickness of (1.0-1.5) mm reduce thermal conductivity of the walls of piping systems more than ten-fold though outside they seem to look quite secure. Deposits begin their formation mainly as calcium carbonate where microorganisms are fixed at. The example of turbine condensers shows how deposits reduce the efficiency of steam turbine units. Intensity of deposits formation and their growth are determined by the quality of cooling water and water mode of circulated cooling systems operation. Nowadays, while developing suggestions for deposits minimization, stationary mode of CCS operation is considered. However, the mode of CCS operation is changeable in time due to scarce water resources. The mode of CCS operation with variable water volume is considered in the work. It is shown that at $V=v a r-C C S$ filling two variants of dependence of salts concentration on time are possible - their increase and decrease. In general, the operating mode of CCS (with respect to water flows) is described by three different dimensionless parameters that are interconnected. Regulatory documentation (SBC B.2.5-74:2013), on the requirements to quality of cooling water and water exchange mode uses models based on assumptions about stationarity of the process and the constant CCS water volume which is not always true. Therefore, the predictive reliability of such documentation is questionable.

Key words: circulated cooling systems, salts concentration, deposition, CCS water volume, water exchange mode.

In Ukraine, one of the largest consumers of water are thermal and nuclear power plants (TPPs and NPPs), almost $90 \%$ of which use circulated cooling systems (CCS). One of the features of CCS that is associated with their function is the evaporation of water. The consequence of evaporation is the concentration of salts in circulated water $(\mathrm{CW})$, which leads to the formation on the technological surfaces of low soluble compounds, in particular, calcium carbonate. Deposits have a coefficient of thermal conductivity ten times lower than structural materials and reduce the coefficients of heat transfer of thermal engineering systems, resulting in losses of heat, water and reagents and reduction of the efficiency of enterprises in general [1-5]. For example, depending on the conditions deposits with a thickness of $1 \mathrm{~mm}$ cause energy over-consumption by $(4 \ldots 15) \%$.

Systematic counteraction to the deposition and optimization of the operating mode of the CCS requires understanding of the physical and chemical processes occurring in the technological cycle of $\mathrm{CW}$ and physically transparent and adequate mathematical models of these processes. Existing models [1-3] of salts concentration in CCS do not take into account the features that accompany the formation of deposits and unsteadiness associated with changes in CCS water regime, in particular, changes in volume, imbalance of water exchange flows and seasonal changes in feed water quality. 
The main elements of CCS (Fig. 1) are the water source, the water supply system, the pumping stations, the coolers (cooling towers, spray pools or ponds) and technological heat exchangers. The water heated in technological heat exchangers is cooled, for example, in cooling towers, by evaporation and convective heat exchange, and is returned to the system due to heat dissipation in the environment.

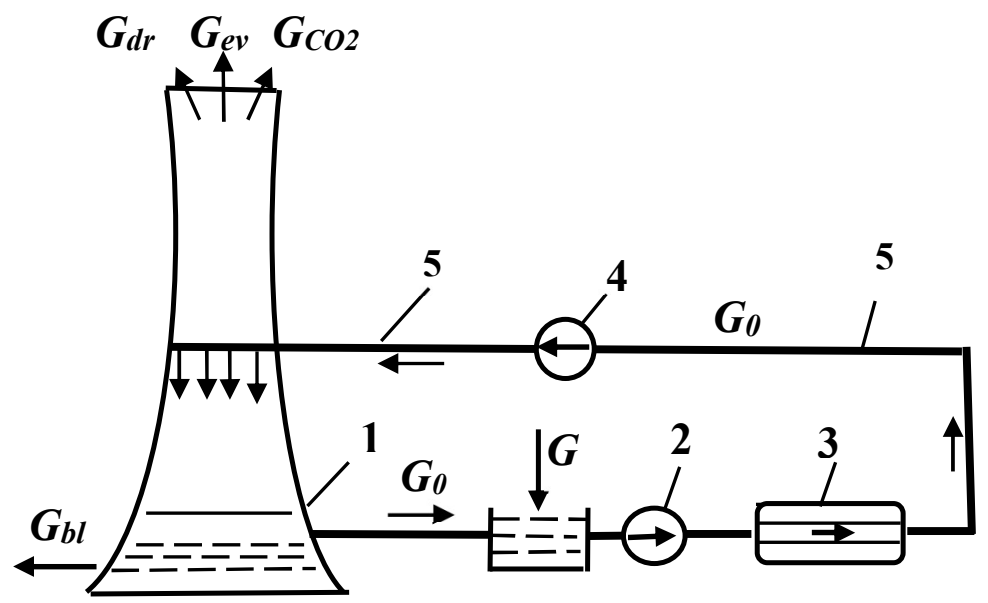

Fig. 1. Diagram of the CCS: 1 - cooler (cooling tower); 2 - circulation pump; 3 - technological heat exchangers; 4 cooling tower pump; 5 - water supply system; $\mathrm{G}_{\mathrm{dr}}$ - cost of drop flow; $\mathrm{G}_{\mathrm{ev}}$ evaporation cost; $\mathrm{G}_{b l}$ - the cost of controlled blowing; $\mathrm{G}_{\mathrm{f}}$ - the cost of feeding; $\mathrm{G}_{0}$ - cost of circulation flow, all costs in $\mathrm{m}^{3} / \mathrm{h}, \mathrm{G}_{\mathrm{CO} 2}$ - cost of carbon dioxide from $\mathrm{CW}, \mathrm{mol} / \mathrm{h}$.

The purpose of the work is to develop a dynamic model of concentration of soluble and low soluble salts in order to reduce calcium carbonate deposits in the waters of CCS, which is an urgent scientific and technical task.

According to [6] the relative costs of the main CCS flows are denoted as

$$
P_{\mathrm{f}}=100 \cdot \frac{G_{f}}{G_{0}}, P_{1}=100 \cdot \frac{G_{e v}}{G_{0}} ; P_{2}=100 \cdot \frac{G_{\mathrm{dr}}}{G_{0}}, P_{3}=100 \cdot \frac{G_{\mathrm{bl}}}{G_{0}} ;
$$

$P_{1} \ldots P_{3}$ costs are normalized by [6, SBC .2.5-74: 2013]. According to the results of studies $[1,2,6,7]$ they should be within $P_{1}=1,0 \ldots 1,5 \% ; P_{2}=0.1 \ldots 2.5 \% ; P_{3}=1,0 \ldots 7,0 \%$, depending on the type of CCS and the method of regulating the stability of the CW. It is worth noting that in [6] stationary modes of CCS are considered, whereas today, due to acute water shortage, such modes are rather the exception than usual.

The total salt content of CW is determined by the balance of salts introduced by the feed water and their removal from the system by blowing. Salts are also carried out by filtration and drop flows. Evaporation does not change the total amount of salts, but affects their concentration in CW.

Let us denote the effective blowing of the $P_{b l}$ :

$$
P_{b l}=P_{2}+P_{3} \text {. }
$$

The losses of $\mathrm{CW}$ are compensated by feed water, the relative flow of which in the case of constant water volume (not always recognized by staff and researchers) is as follows:

$$
P_{f}=P_{e v}+P_{b l}
$$

The costs of feeding, evaporation and blowing are characteristic values, they are called the parameters of the water regime.

The concentration of salts in the CCS compared to the initial one of feed water is increased in the $\mathrm{CW}$ cycle. These changes depend on the solubility of the salts, the physical and chemical processes along the $\mathrm{CW}$ path, the phase-dispersed state of the impurities, as well as the water regime of the system. In addition, salt concentrations depend on the time elapsed since the start of the process, the dynamics of the main flows of the system and the concentration of salts in the feed water. In general, the concentrations of soluble salts in $\mathrm{CW}$ are normalized by the boundary acceptable concentration of salts. The components coming with the feed water to the CCS are divided into two groups $[2,5]$ :

1) soluble, which do not precipitate under any technological process modes (these are salts of strong acids, for example, $\mathrm{KCl}, \mathrm{NaCl}, \mathrm{CaCl}_{2}, \mathrm{MgCl}_{2}$ ) - they are often called tracers [2]; 
2) low soluble components, which under certain conditions of operation of the CCS undergo physical and chemical changes, for example, precipitate $\left(\mathrm{CaCO}_{3}, \mathrm{CaSO}_{4}, \mathrm{Mg}(\mathrm{OH})_{2}, \mathrm{FeCO}_{3}, \mathrm{Fe}\right.$ $\left.(\mathrm{OH})_{3}\right)$, and form deposits. The term scale forming substances is used for them.

Thermophysical properties of some types of deposits are presented in table 1 .

We draw your attention to the data in Table 1, from which it follows that jelly-like organic and silicon deposits are more dangerous in reducing the heat transfer coefficient of heat exchangers than solid carbonates, since their thermal conductivity coefficient is $1.5-2.5$ times smaller than carbonate ones. The components of the second group lead to contamination of the surfaces of the waterway.

Table 1. Thermophysical properties of deposits [8]

\begin{tabular}{|c|c|c|c|}
\hline $\begin{array}{l}\text { Thermophysical } \\
\text { Typerties of deposits }\end{array}$ & $\begin{array}{l}\text { Thermal } \\
\text { conductivity, } \\
W /(m \cdot K)\end{array}$ & $\begin{array}{l}\text { Heat } \\
\text { capacity, } \\
\mathrm{kJ} /(\mathrm{kg} \cdot \mathrm{K})\end{array}$ & Density, \\
\hline $\begin{array}{l}\text { Deposits of the } \mathrm{CW} \text { of cast iron casting } \\
\text { machines }\end{array}$ & 1,3 & 0,9 & 1830 \\
\hline $\begin{array}{l}\text { Deposits on the surface of the pipeline } \\
\text { of the ESPC- } 20 \mathrm{VG} \text { furnace }\end{array}$ & 1,27 & 0,88 & 2280 \\
\hline $\begin{array}{l}\text { Deposits in the tubes of the condensers } \\
\text { of the thermoelectric plant }\end{array}$ & 1,29 & 0,88 & 2230 \\
\hline Deposit after phosphating & 0,91 & 0,83 & 1670 \\
\hline Deposits of protective carbonate film & 1,3 & 0,91 & 2380 \\
\hline Deposits in the gas pipeline & 1,12 & 0,84 & 1800 \\
\hline $\begin{array}{l}\text { Deposits after hydrocyclones }(\mathrm{h} / \mathrm{c}) \text { of } \\
\text { gas cleaning of blast furnace }(\mathrm{g} / \mathrm{c} \text { of } \mathrm{BF})\end{array}$ & 1,32 & 0,9 & 2707 \\
\hline Slime of evaporated water $\mathrm{g} / \mathrm{c}$ of BF & 1,31 & 0,63 & 1570 \\
\hline $\begin{array}{l}\text { Deposits after } \mathrm{h} / \mathrm{c} \text { of the } \mathrm{CW} \text { supply } \\
\text { cycle. } \mathrm{g} / \mathrm{c} \text { of BF with } \mathrm{k}=5.26\end{array}$ & 1,32 & 0,91 & 2736 \\
\hline Solid carbonate deposits & 2,1 & 0,99 & 2380 \\
\hline Mucous deposits of organic nature & 0,82 & 3,46 & 1107 \\
\hline Jelly deposits of silicon-organic nature & 1,08 & 3,90 & 1236 \\
\hline $\begin{array}{l}\text { Deposits after } \mathrm{h} / \mathrm{c} \text { of the } \mathrm{CW} \text { supply } \\
\text { cycle of the sinter factory with } \mathrm{k}=2,62\end{array}$ & 1,34 & 0,88 & 2698 \\
\hline
\end{tabular}

Due to the fact that the deposits have a coefficient of thermal conductivity ten times lower than that of structural materials (for boiler steel St-20 $\lambda=54.3 \mathrm{~W} /(\mathrm{m} \cdot \mathrm{K})$, for material CuNiFe 5-1 $\lambda=135$, and deposits $(0.7 \ldots 3.5) \mathrm{W} /(\mathrm{m} \cdot \mathrm{K}))$, even its thin layer can reduce by several times the heat transfer coefficient and the efficiency of power plants. Organic mucous deposits with thermal conductivity of $\lambda=(0.7 \ldots 1.2) \mathrm{W} /(\mathrm{m} \cdot \mathrm{K})$ are particularly dangerous. Therefore, their layer of $\delta l_{s c}=(0.5 \ldots 1.3) \mathrm{mm}$ thickness is equivalent in terms of losses of the coefficient of thermal conductivity on the layer of carbonate deposits of $(0.75 \ldots 3.2) \mathrm{mm}$. The coefficient of thermal conductivity of the wall of $l_{w}$ thickness, which is covered with a layer of scale $\delta l_{s c}$, is given by the expression [9]:

$$
\lambda(\delta)=\frac{\lambda_{w}}{\frac{l_{w}}{l_{w}+\delta l_{s c}}+\frac{\delta l_{s c}}{l_{w}+\delta l_{s c}} \cdot \frac{\lambda_{w}}{\lambda_{s c}}}
$$


The calculation by (4) is shown in Fig. 2.

We can see that deposits with a thickness of $1 \mathrm{~mm}$ result in a decrease in the thermal conductivity of the wall more than 10 times.

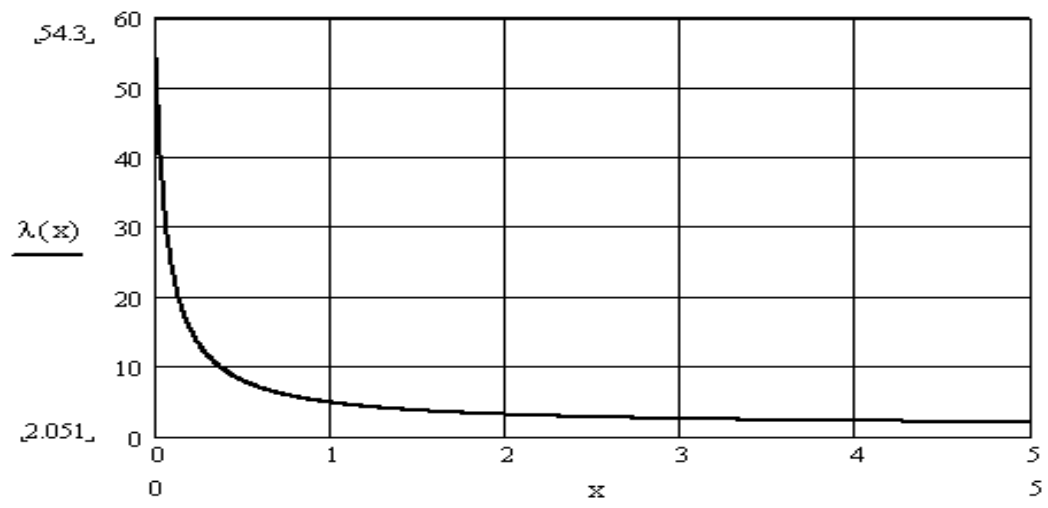

Fig. 2. Dependence of the thermal conductivity of the heat exchanger wall of steel-20, $\lambda_{s t}=54.3$, covered with scale of $\lambda s c=1.7 \mathrm{~W} /(\mathrm{m} \cdot \mathrm{K})$, of the $x \mathrm{~mm}$ thickness.

Contamination of the pipe system (PS) of the turbine capacitors (TC) with deposits causes the temperature increase in the condensers vapor space and, accordingly, the pressure therein. The temperature $t(\delta)$ in the steam space of TC with PS covered with deposits with thickness $\delta$ is calculated by [9],

$$
t(\delta)=t_{2} \cdot\left[1+\left(1-\frac{t_{1}}{t_{2}}\right) \cdot\left(\left(\frac{t_{v p}^{0}-t_{1}}{t_{v p}^{0}-t_{2}}\right)^{\frac{1}{1+K_{0} \cdot \frac{\delta}{\lambda}}}-1\right)^{-1}\right]
$$

$t_{1}-\mathrm{CW}$ inlet temperatures; $t_{2}$ - outlet temperatures from TC; $t_{v p}{ }^{0}$ - is the temperature in the vapor space of pure TC; $\delta, \lambda$ are the thickness and thermal conductivity of the deposits layer; $K_{0}$ is the heat transfer coefficient of pure TC. The temperatures $t_{1}$ and $t_{2}$ are interconnected,

$$
\Delta t=t_{2}-t_{1}=\frac{520}{m}, \quad m=\frac{G_{0}}{D_{\mathrm{st}}},
$$

$m$ - is the multiplicity of cooling; $D_{s t}$ - steam consumption in $\mathrm{TC}, \mathrm{kg} / \mathrm{s}$.

The result of the calculation of the temperature increase $\delta t_{s t}$ in the steam space of the TC of K300-240 unit, depending on the thickness of deposits, provided that the coefficient of heat transfer of pure PS of the TC $K_{0}=3300 \mathrm{~W} /\left(\mathrm{m}^{2} \cdot \mathrm{K}\right), \lambda=1.5 \mathrm{~W} /(\mathrm{m} \cdot \mathrm{K}), t_{2}-t_{1}=12^{\circ} \mathrm{C}$ is shown in Fig. 3.

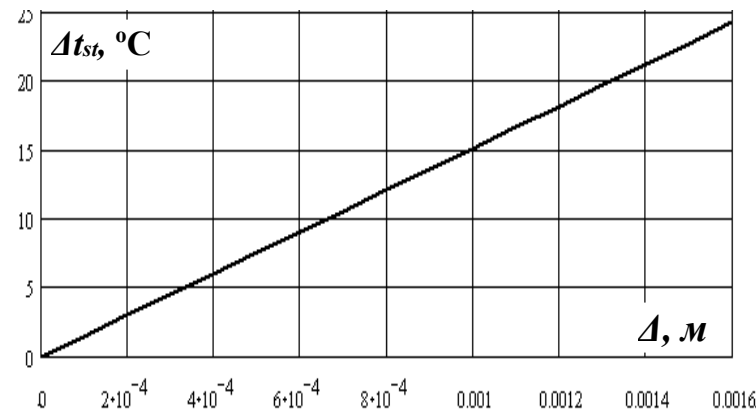

Fig. 3. Dependence of temperature increase, $\delta \mathrm{t}_{\mathrm{st}}{ }^{\circ} \mathrm{C}$, in the steam space of $\mathrm{TC}$ on the thickness $\Delta$ of deposits on the pipe system.

It can be shown $[9,10]$ that the approximate dependence of $K(\delta)$ has the form

$$
K(\delta)=K_{0} /\left(1+K_{0} \cdot \frac{\delta}{\lambda}\right)
$$


The dependence $K(\delta)$ for the TC of the K-300-240 unit is shown in Fig. 4.



Fig. 4. Dependence of $K(\delta)$ on the thickness of the deposits $\delta, m$. For curves 1...4, deposits thermal conductivity $\lambda=0.5 ; 1.0 ; 2.5$ and 3.5 $W /(m \cdot K)$.

We can see (curve 2 in Fig. 4), that a layer of $1 \mathrm{~mm}$ thickness with a thermal conductivity of $1 \mathrm{~W} /(\mathrm{m} \cdot \mathrm{K})$ reduces the heat transfer coefficient by 4.1 times.

This results in pressure increase in TC and the efficiency reduction of the unit [9,10]. According to Fig. 3 and the tables of the saturated steam state we find the interpolation dependence of the pressure in the TC on the thickness of the deposits,

$$
P_{2}(\delta)=10^{-3} \cdot\left[13.039-0.68 \cdot t(\delta)+0.0133 \cdot t(\delta)^{2}\right] M P a . t(\delta)=30+\delta t,{ }^{o} C .
$$

According to this dependence, the loss of gross electric efficiency of K - 300-240 unit from the thickness of deposits was calculated. The result is shown in Fig. 5 . It can be seen that $\approx 1 \mathrm{~mm}$ thick deposits, which are considered acceptable by operating personnel, reduce the efficiency by $1.5 \%$, which results in power loss of $\approx 13 \mathrm{MW}$ for the $300 \mathrm{MW}$ unit.

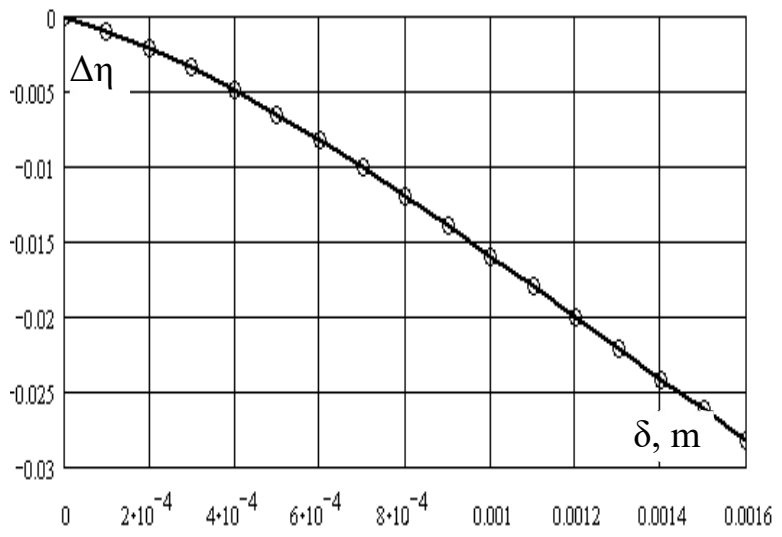

Fig. 5. Dependence of change of electric efficiency of K300-240 unit on the thickness of the layer of deposits $\delta$ on the pipe system of TC. It should be noted that the thickness of the deposits of $1 \mathrm{~mm}$ reduces the efficiency of the unit by $\approx 1.5 \%$.

During the operation of CCS, it is important to know the concentrations of soluble and low soluble components at a certain period of time to predict their evolution and to correct the rate of growth of deposits and inhibition of corrosion processes. To do this, it is necessary to establish the dependences of the concentration of salts on time and to determine the parameters (mode factors) that are decisive for the change of concentrations compared to the initial ones.

The differential equation for soluble components has the form [2],

$$
d M=C_{0} \cdot\left(q_{1}+q_{2}+q_{3}\right) d t-C \cdot\left(q_{2}+q_{3}\right) d t, \quad q_{i}=\frac{G_{0}}{100} \cdot P_{i},
$$

where $d M$ is the change in the amount of salt in the system during $d t ; C_{0}$ - salt concentration in feed water; $C$ - is the concentration of the same salt in circulating water at time $t$.

In [2] it is assumed that the total amount of salt in the system $M(\mathrm{~kg})$, the volume of water $V$ $\left(\mathrm{m}^{3}\right)$, the total turnover $G_{0}\left(\mathrm{~m}^{3} / \mathrm{h}\right)$ and the duration of one cycle $T(\mathrm{~h})$ are connected by the relations: $V$ $=G_{0} \cdot T$.

Note that (9) corresponds to the taciturn assumption of a homogeneous distribution of concentrations of circulating water components (perfect mixing) and of the constancy of the water volume of the CCS and the CW consumption. 
The solution (9) is known under the specified conditions [2],

$$
C(t)=C_{\lim }-C_{0} \cdot \frac{P_{1}}{P_{2}+P_{3}} \cdot \exp \left(-\frac{P_{2}+P_{3}}{T} \cdot t\right), \quad C_{\lim }=C_{0} \cdot\left(1+\frac{P_{1}}{P_{2}+P_{3}}\right),
$$

$\mathrm{C}_{\text {lim }}$ - limit $(\mathrm{t} \rightarrow \infty)$ concentration of soluble salt (tracers).

To characterize the relative change in the concentration of salts in $\mathrm{CW}$ compared to the feed water, a parameter called the salt concentration coefficient $k$ is used and referred to as $k(t)=C(t) / C_{0}$, $C_{0}$ - the concentration of salts in the feed water. Then in terms of $k(t)$, relationship (10) takes the form

$$
k(t)=k_{\imath p}-\left(k_{2 p}-1\right) \cdot \exp \left(-\frac{P_{1}}{k_{\imath p}-1} \cdot \frac{t}{T}\right), \quad k_{\lim }=\lim _{t \rightarrow \infty} k(t)=1+\frac{P_{1}}{P_{2}+P_{3}} .
$$

Note that $k_{\text {lim }}$ under conditions of CCS constancy of water volume of is equal to the evaporation coefficient of CW $k_{e v}$, which in [6] is defined as:

$$
k_{e v}=1+\frac{P_{1}}{P_{1}+P_{2}}=1+\frac{P_{e v}}{P_{b l}} .
$$

It is important that $k(t)$ and $k_{e v}$ are two different parameters that characterize the operating mode of the CCS.

Only when equilibrium is reached in the CCS, or it operates in the stationary regime they become equal, $k(t \rightarrow \infty)=k_{\text {lim }}=k_{e v}$.

We model the CCS regime with variable water volume by accepting:

- all flows are constants in time;

- CCS operates in the mode of $q_{f}=0$, that is, emptying.

The equation of the change of salt mass in CCS for this regime is the following:

$$
d M(t)=-C \cdot q_{b l} \cdot d t
$$

at $q_{e v}+q_{b l}=$ Const CCS water volume is changed linearly in time,

$$
V(t)=V_{0}-\left(q_{e v}+q_{b l}\right) \cdot t=V_{0} \cdot\left(1-t / \tau_{e m}\right), \tau_{e m}=V_{0} /\left(q_{e v}+q_{b l}\right), t>t_{0},
$$

then the dependence $\mathrm{C}(\mathrm{t})$ takes the form

$$
C(t)=C_{0} \cdot\left(\frac{V_{0}}{V(t)}\right)^{\frac{q_{e v}}{q_{b l}+q_{e v}}}=C_{0} \cdot\left(1-\frac{t}{\tau_{\mathrm{em}}}\right)^{-\frac{1}{1+\frac{q_{b l}}{q_{e v}}}},
$$

$\tau_{e m}$ - the time of emptying during which the CCS is dried over all channels, including evaporation.

Dependence of the concentration coefficient on time is

$$
k(t)=k_{0} \cdot\left(\frac{V_{0}}{V(t)}\right)^{\frac{1}{1+\frac{q_{b l}}{q_{e v}}}} .
$$

It is obvious that $\tau_{b l}>\tau_{e m} ; k_{0}=k(0)$. The calculation of $k(t)$ is shown in Fig. 6. From the figure we can see that during the mode of emptying (draining) $\left(q_{f}=0\right)$ at ar constant speed, $d V / d t=$ Const $<0$, salts in CCS with small changes in volume are concentrated according to a linear law: the more intensive is the concentration, the greater is the water consumption for evaporation. 




Fig. 6. Dependence of the coefficient $k$ in the drainage regime, see (16), on the relative change in the volume $x(t)=V_{0} / V(t)$ for the values $q_{b} / q_{e v}=0.1,0.3,0.5$, and 0.7 of curves 1 ... 4. Accepted thet $k_{0}=1$.

The mode of filling the CCS with a constant feed water supply is modeled similarly to the mode of emptying. The change in the amount of salts in the CCS is expressed by the equation:

$$
d(V(t) \cdot C(t))=C_{0} \cdot q_{f} \cdot d t-C(t) q_{b l} \cdot d t .
$$

When a CCS is filled with constant $q_{f}$ its volume is increased by the law,

$$
\frac{d V}{d t}=q_{f}-q_{b l}-q_{e v}=q^{+}=\text {Const; } V(t)=V_{0}+q^{+} \cdot\left(t-t_{0}\right) .
$$

Combining (17) and (18), we obtain the equation for $\mathrm{C}(\mathrm{t})$,

$$
\frac{d C}{d t}=\frac{q_{\mathrm{f}}}{\varphi \cdot V(t)} \cdot\left(\varphi \cdot C_{0}-C\right) .
$$

$\varphi$ is a dynamic (mode) CCS parameter that we introduced in [9],

$$
\varphi=\frac{q_{f}}{q_{f}-q_{e v}}=\frac{q_{f}}{q_{b l}+q^{+}}=\frac{k_{e v}}{1+\frac{q^{+}}{q_{b l}}} ; \quad k_{e v}=\frac{q_{f}}{q_{b l}}=1+\frac{q^{+}}{q_{b l}}+\frac{q_{e v}}{q_{b l}}
$$

The solution (19) under the condition of (18) is given by the expression:

$$
C(t)=k(t) \cdot C_{0} ; \quad k(t)=\varphi-\left(\varphi-k_{0}\right) \cdot\left[\frac{V_{O}}{V(t)}\right]^{\left(\frac{1}{1-\frac{\varphi}{k_{e v}}}\right)}, \quad k_{O}=\frac{C\left(t_{O}\right)}{C_{0}} \cdot t_{0}=\frac{V_{0}}{q^{+}} ; t>t_{0}
$$

As we can see from (21), the difference between $k(t)$ and $k_{e v}$ is clearly evident in CCS operating in non-stationary modes with variable water volume or variable CCS flows. Having denoted $y=$ $q_{e v} / q_{b l}, z=q^{+} / q_{b l}$, and $x(t)=V(t) / V_{0}$, we calculated $k(t)$ for different parameter values, see. Fig. 7. It is important that depending on the value of $k_{0}$, the concentration coefficient $k(t)$ with volume growth can be both decreased and increased.

Critical to the behavior of $k(t)$ is the relation between $k_{0}$ and $\varphi$. If $\varphi<k_{0}$, this condition is true for curves 1 and 2 , then $k(t)$ with volume filling is reduced.

The values of the regime parameters that reduce the concentration of salts are calculated by (20). On the contrary, if $\varphi>k_{0}$, see curves 3 and 4 , then $k(t)$ is increased and even an increase in the CCS water volume does not allow a decrease in salt concentrations. 


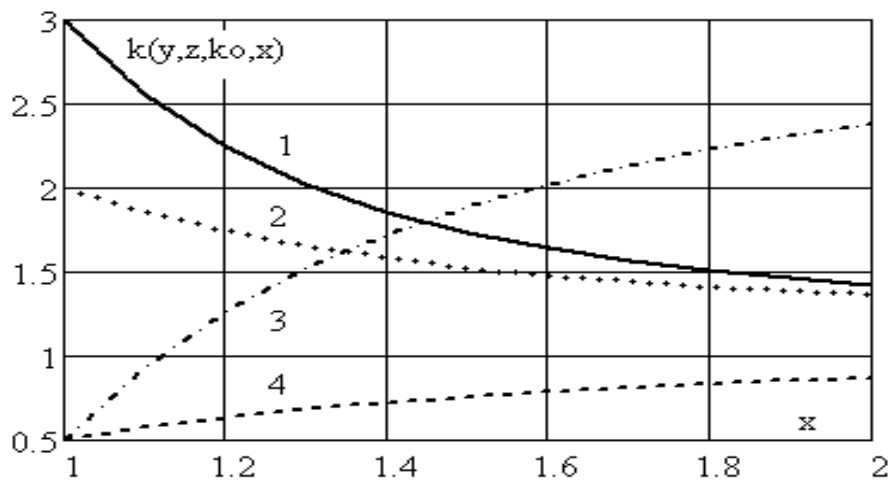

Fig. 7. Dependence of the coefficient of concentration (21) in the mode of filling with a constant rate of relative change of volume $x=V(t) / V o$ ) at values - curve 1 : $(0.3 ; 0.5 ; 3 ; x)$, curve $2:(0.3 ; 1 ; 2 ; x)$, curve 3 : $(0.2 ; 2 ; 0.5 ; x)$, curve $4:(4 ; 1 ; 0.5 ; x)$.

These features should be taken into account while manipulating flows to control the degree of concentration of salts in CCS.

Formulas (16) - (21) represent the procedure for calculating the desired degree of concentration of salts and the values of flows that provide it.

Expression (21) indicates that, in general, the operating mode (with respect to water flows) of a CCS is described by three different dimensionless parameters $k, k_{e v}$ and $\varphi$, which are interconnected. It follows from (20) that in the case of constant water volume $\left(q^{+}=0\right)$ the parameters $\varphi$ and $k_{e v}$ coincide. In the same case, when the CCS approaches the equilibrium, then $k \rightarrow k_{e v} \rightarrow \varphi$.

Therefore, dependence (21) simultaneously shows the relationship and emphasizes the difference between the parameter $\varphi$, the concentration coefficients of salts $k$ and the evaporation of $k_{e v}$, which are often confused in the scientific works. These coefficients are the same for CCS that operate with a constant water volume and are in equilibrium or stationary states.

\section{Summary}

1. The main problem associated with the operation of CCS that use untreated (raw) water is the deposits that occur on technological surfaces, in particular, on TC 0f power plants. They reduce the intensity of heat transfer and disrupt the technological processes.

2. The formation of deposits is mainly connected with the concentration of salts in the circulating water due to its evaporation. It is possible to reduce the intensity of deposits due to water evaporation by applying reagent treatment or pre-treatment of feed water (for example, by clarification) to such concentrations of scaleforming substances in it that $k_{e v} \cdot C_{0}<C_{c r}, C_{c r}$ - the concentration $[5,10]$ at which deposition begins.

3. The example of TC shows how deposits affect the vacuum in the steam space of the TC, and thus reduce steam turbine unit efficiency and reduce power generation at condensing power plants.

4. It is shown that at $V=v a r$ - the mode of dehydration, the concentration of salts in the CCS is always increasing, but in the mode of CCS filling, two variants of dependence of the concentration of salts on time are possible. If $\varphi<k_{0}$, then the concentration of salts is decreased at filling, and if $\varphi$ $>k_{0}$, on the contrary - it is increased. This feature should be taken into account while regulating water flows.

5. Generally, the operating mode of CCS (with respect to water flows) is described by the dimensionless parameters $k(t), k_{e v}$ and $\varphi(t)$ that are interconnected. In the case of constant water volume and mode parameters, the values of $\varphi$ and $k_{e v}$ coincide. As the CCS approaches the equilibrium then $k \rightarrow k_{e v} \rightarrow \varphi$.

6. Today, regulatory documents [6] use models of water exchange based on assumptions about the stationarity of the regime and the constant volume of CCS, which is not always true. Therefore, the predictive reliability of such documentation is questionable.

\section{References}

1. Abramov N.N. Water Supply. Moscow: Strojizdat. - 1982.- 440 s.

2. Kucherenko D.I., Gladkov V.A. Circulating water supply. (Water Cooling Systems). Moscow: Stroyizdat. - 1980. - 169 s.

3. Shabalin. A.F. Circulated water supply of industrial enterprises. Moscow: Publ. House on constructions. 1972. $-296 \mathrm{~s}$. 
4. Kochmarskii V.Z., Pospelov D.N. The state of the problem of anti-flood water treatment in the USSR. - Kyiv: - Knowledge. - 1986 - 20 s.

5. Gayevskyi V.R., Kochmarskii V.Z. Increase of effectiveness of circulation cooling systems by minimization of calcium carbonate deposits. Publ. NUWMEE. Rivne. 2018. - 154 s. ISBN 978966-327-38309.

6. State Building Code (SBC) V.2.5-74: 2013. External networks and facilities. Basic design points.

7. Andronov V.A. Main dependences characterizing salt (material)and water balances of circulating cooling systems of industrial enterprises// Public utilities of the cities. -2004 . - Ed. 60. S. $151-155$.

8. Kruchkov S.N., Nazarenko A.N. On the issue of heat conductivity of deposits on the surfaces of heat exchange and in the pipes of metallurgical aggregates // Works of Zaporizzia State Engineering Academi. Metallurgy. - 2001. -Ed. 4. - S. 140-142.

9. Kochmarskii V.Z., Kochmarskii O.V. Deposits in circulating systems of heat power plants. // Heat engineering. New challenges of the time. Bulletin of scientific papers. Editors: Omelianovskyi, V. Mysak. - Lviv: - Ukrainian technologies. - 2009. - Pp. 535-546.

10. Shelepov I.G., Mihaiskij D.V. Investigating the influence of NPC operation regimes on the efficiency of the power unit operation.// Eastern European Journal of Transmission Technologies, "Technological Center". Kharkiv: - 2005. - No. 3 (2) .- P. 122-125.

\title{
КОНЦЕНТРУВАННЯ СОЛЕЙ ТА ВІДКЛАДЕННЯ В СИСТЕМАХ ОХОЛОДЖЕННЯ ЕЛЕКТРОСТАНЦЙ
}

\author{
Кочмарський В.3., Куба В.В. \\ Національний університет водного господарства і природокористування (НУВГП), м. Рівне. \\ Фізико-технологічна лабораторія водних систем. v.z.kochmarskii@nuwm.edu.ua
}

Аналізується робота оборотних систем охолодження (ОСО), умови утворення твердих відкладень та їх вплив на коефіцієнт теплопередачі теплообмінників. Звертається увага на особливу небезпеку слизистих (переважно органічних) відкладень, що мають коефіцієнт теплопровідності менший від $1 \mathrm{BT} /(\mathrm{м} \cdot \mathrm{K})$. Відкладення такого типу товщиною всього (1.01.5)мм знижують теплопровідність стінок трубних систем більш ніж у десять раз, хоча ззовні вони виглядають зовсім безпечними. Переважно відкладення починають формуватися у вигляді карбонату кальцію на який закріпляються мікроорганізми. На прикладі конденсаторів турбін показано, як відкладення знижують ККД паротурбінних установок. Інтенсивність утворення і росту відкладень визначається якістю охолодної води та водним режимом роботи OCO. На сьогодні, при розробці рекомендацій щодо мінімізації відкладень, розглядають стаціонарний режим роботи ОСО. Проте, в останні роки внаслідок дефіциту водних ресурсів режим роботи ОСО змінний у часі. В роботі розглядається режим роботи систем охолодження зі змінним водним об'ємом. Показано, що при V = var - наповненні ОСО, можливі два варіанти залежності концентрацій солей від часу - їх збільшення та зменшення. Загалом режим роботи ОСО(щодо водних потоків) описується трьома різними безрозмірними параметрами, які зв'язані між собою. Нормативна документація (ДБН В.2.5-74:2013.), що регулює вимоги до якості охолодних вод та режимів водообміну використовує моделі, що грунтуються на допущеннях про стаціонарність процесу та постійному водному об'ємі ОСО, що не завжди відповідає дійсності. Тому прогностична надійність такої документації сумнівна.

Ключові слова: оборотні системи охолодження, концентрування солей, відкладення, водний об'єм ОСО, режим водообміну. 


\section{КОНЦЕНТРИРОВАНИЕ СОЛЕЙ И ОТЛОЖЕНИЯ \\ В СИСТЕМАХ ОХЛАЖДЕНИЯ ЭЛЕКТРОСТАНЦИЙ}

\section{Кочмарський В.3., Куба В.В.}

Национальный университет водного хозяйства и природопользования (НУВХП), г. Ривнэ. Физико-технологическая лаборатория водных систем. v.z.kochmarskii@nuwm.edu.ua

Анализируется работа оборотных систем охлаждения (ОСО), условия образования твердых отложений и их влияние на коэффициент теплопередачи теплообменников. Обращается внимание на особенную опасность слизистых (преимущественно органических) отложений, с коэффициентом теплопроводности меньшим от $1 \mathrm{Bm} /(\mathrm{s} \cdot \mathrm{K})$. Отложения такого типа толщинной всего (1.0-1.5)мм снижают теплопроводность стенок трубных систем более чем у десять раз, хотя внешне они выглядят совершенно безопасными. Преимущественно отложения начинают формироваться в виде карбоната кальция на котором закрепляются микроорганизмыл. На примере конденсаторов турбин показано, что отложения снижают ККД паротурбинных установок. Интенсивность образования и роста отложений определяется качеством охлаждающей воды и водным режимом работы ОСО. В настоящее время при разработке рекомендаций по минимизации отложений, рассматривают стационарный режим работы ОСО. Но в последнее время, вследствие дефицита водных ресурсов, режим работы ОСО преимущественно переменный во времени. В работе рассматривается режим работы систем охлаждения с переменным водным объемом. Показано, что при $\boldsymbol{V}=$ var - наполнении ОСО, возможны два варианта зависимости концентрации солей от времени - их рост и уменьшение. Вообще, режим работь ОСО(касательно водных потоков) описывается тремя разными безразмерными параметрами, связанными между собой. Нормативная документация (ДБН В.2.5-74:2013.), регулирующая требования к качеству охлаждающих вод и режимов водообмена использует модели, основанные на предположениях о стационарности процесса и постоянстве водного объема ОСО, что не всегда соответствует действительности. Поэтому прогностическая надежность такой документации сомнительна.

Ключевые слова: оборотные системы охлаждения, концентрирование солей, отложения, водный объем ОСО, режим водообмена. 